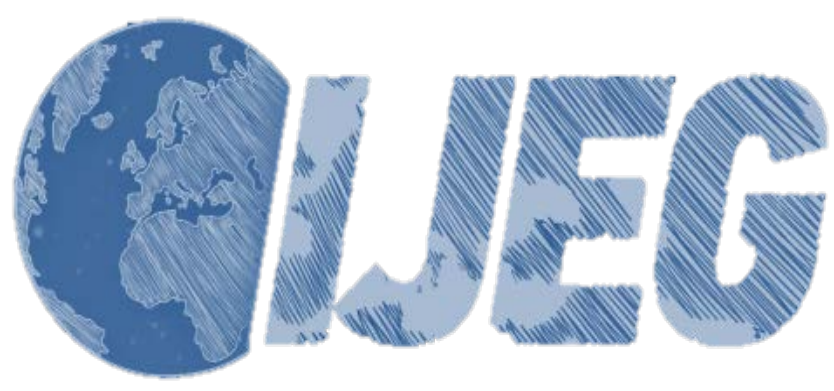

International Journal of Engineering and Geosciences (IJEG), Vol; 4, Issue; 1, pp. 016-027, February, 2019, ISSN 2548-0960, Turkey, DOI: $10.26833 /$ ijeg.417151

\title{
INVESTIGATING LAND SURFACE TEMPERATURE CHANGES USING LANDSAT-5 DATA AND REAL-TIME INFRARED THERMOMETER MEASUREMENTS AT KONYA CLOSED BASIN IN TURKEY
}

\author{
Osman Orhan ${ }^{1}$ Filiz Dadaser-Celik ${ }^{2}$ and Semih Ekercin ${ }^{3 *}$ \\ ${ }^{1}$ Konya Technical University, Faculty of Engineering and Natural Sciences, Department of Geomatic Engineering, \\ Konya, Turkey (orhanosman44@gmail.com); ORCID 0000-0002-1362-8206 \\ ${ }^{2}$ Erciyes University, Faculty of Engineering, Department of Environmental Engineering, Kayseri/TURKEY. \\ (fdadaser@erciyes.edu.tr); ORCID 0000-0003-3623-7723 \\ ${ }^{3}$ Aksaray University, Engineering Faculty, Department of Geomatic Engineering, Aksaray, Turkey \\ (ekercin@gmail.com) ORCID 0000-0002-9458-2261
}

*Corresponding Author, Received: 20/04/2018, Accepted: 15/07/2018

\begin{abstract}
The main purpose of this paper is to investigate multi-temporal land surface temperature (LST) changes of Konya Closed Basin (KCB) in Turkey using remotely sensed data. KCB is located in the semi-arid central Anatolian region of Turkey and hosts many important wetland sites including Salt Lake. Six Landsat-5 TM images selected from the 19842011 period were used in the analysis. A real-time field work was performed during the overpass of Landsat-5 satellite on 21/08/2011 over Salt Lake to collect coordinated temperature measurements using a handheld GPS and thermal infrared thermometer. All satellite images were geometrically and radiometrically corrected to relate the image data with in-situ measurements. Thematic LST images were used to evaluate the conditions over the region between 1984 and 2011. The results show that real-time ground temperature and satellite remote sensing data were in good agreement with correlation coefficient (R2) values of 0.94 . The remotely sensed and processed satellite images and resulting thematic indices maps show that dramatic land surface temperature changes occurred (about $2^{\circ} \mathrm{C}$ ) in the KCB from 1984 to 2011. Analysis of climatic data supports this finding. Air temperatures and pan evaporation had significant upward trends from 1984 to 2011. Analysis conducted using both LST and climatic data prove that the basin has been experiencing drought in recent years. It is suggested that the use of water supplies, especially ground water should be controlled taking into account particularly summer drought impacts over the basin.
\end{abstract}

Keywords: Konya Closed Basin, climate change, satellite remote sensing, Landsat-5 TM, land surface temperature, infrared thermometer. 


\section{INTRODUCTION}

The surface energy balance, atmospheric state, and thermal properties of the surface and subsurface dramatically affect and control the land surface temperature (LST) (Srivastava et al., 2009). LST is one of the important parameters in many environmental applications including modelling energy and material exchange between atmosphere and land, global oceanflow cycle, and climate change, and weather forecasting.

LST has been proved to be an important factor controlling the physical, chemical and biological processes on Earth's surface (Qin and Karnieli 1999). It is a key parameter in models of radiation budget, energy balance and water circulation on the ground at different scales. For instance, LST is necessary for calculating the net radiation flux by quantifying the outgoing long-wave radiation flux of the ground (Bastiaanssen and Menenti 1998, Su 2002, Cai et al. 2007). Moreover, LST is needed to infer the sensible heat flux in surface energy balance models, such as the one-layer model (Jiang and Islam 2001), the two-layer model (Chen et al. 2005) or the twosource model (Kustas and Norman, 1999).

Thermal remote sensors on board satellites and aircraft offer the possibility to obtain spatially distributed LST data. Polar orbit platforms such as NOAA-AVHRR (National Oceanic and Atmospheric Administration Advanced Very High Resolution Radiometer), Landsat TM/ETM+ (Thematic Mapper/ Enhanced Thematic Mapper), Terra/Aqua MODIS (Moderate Resolution Imaging Spectroradiometer) and Terra ASTER (Advanced Spaceborne Thermal Emission and Reflection Radiometer) provide images at various scales. However, retrieving LST from thermal remotesensing images is a difficult task, numerous schemes with varying degrees of complexity were developed to estimate the LST from thermal infrared images acquired by different sensors. These methods depend on the specifications of thermal sensors. For example, the classical split-window algorithms were established for sensors with two or more thermal channels such as AVHRR, while the temperature/emissivity separation method was developed for ASTER and MODIS, which have five or more channels in the thermal infrared region (Gillespie et al. 1998). Readers are encouraged to refer to Qin and Karnieli (1999) and Dash et al. (2002) for summaries of these methods.

There are also efforts to combine remotely sensed LST with in-situ air temperature to derive spatial air temperature (Florio et al. 2004). Christóbal et al. (2008) model air temperature by means of multiple regression analysis of in-situ air temperature, remote sensing predictors (LST, albedo and Normalized Difference Vegetation Index, NDVI) and geographical variables (altitude, latitude, continentality, and solar radiation). Nichol and Wong (2008) show that the quality of the correlation between surface and air temperature depends on the spatial scales of data sampling, that is, pixel size and density of in-situ measurements.
This study aims to investigate the LST changes in the Konya Closed Basin (KCB) (Turkey's largest closed basin), Turkey, between 1984 and 2011 using Landsat-5 TM remote sensing data. Our study's results are significant since the surface temperature estimation is necessary to establish the monitoring systems of the heat islands in urban areas, sea surface temperature, and thermal drainage distribution. Our results are also important for environmental managers and ecosystem health.

\section{METHODOLOGY}

\subsection{Study Area}

The Konya Closed Basin (KCB) in Turkey is located in the semi-arid Central Anatolian Plateau at latitude $36^{\circ} 51^{\prime}-39^{\circ} 29^{\prime} \mathrm{N}$ and longitude $31^{\circ} 36^{\prime}-34^{\circ} 52^{\prime} \mathrm{E}$ and at an altitude of about $1,000 \mathrm{~m}$. KCB covers a 5,426,480-ha surface area (nearly $7 \%$ of Turkey's total area) that is larger than that of The Netherlands. Within the basin, there are 11 wetlands including lakes, Samsam, Kozanl, Kulu, Beysehir, Sugla, Bolluk, Tersakan, Tuz (Salt Lake) and marshes Eregli, and Hotamis. A smooth plane at 900$1,050 \mathrm{~m}$ altitude has formed the main part of the Central Anatolia Plateau in KCB, Turkey's largest closed basin in which three million people live, $45 \%$ in rural areas and $55 \%$ in urban areas. The agricultural revenue provided by Konya Closed Basin was due to grains (9.2\%), beans (6.2\%), and industrial crops including sugar beets (8.5\%) (Dogdu et al. 2007).

As a result of insufficient drainage and high groundwater levels, irrigation, and terrestrial semiarid mild climate conditions dominant in the basin, the soils of the region usually have the alluvial and salty characteristics. The water of the basin comes to an end in stagnant water, marshy places, or semi marshy places. The lack of a large river in this wide basin, limited rainfall, and high evaporation ratios have formed a favorable water balance that is rarely met in closed basins. The shallow lake and marshes at the center of the basin are fed by many small streams flowing to the region. The climate characteristics of the basin present the Mediterranean climate (mild and rainy winters, hot and dry summers) at the south, the terrestrial climate (cold winters, hot and dry summers) at the center and north of the basin, and the desert climate in Karapınar and its vicinity located to the southeast of the basin. Precipitation in the basin is mostly observed in winter and spring seasons (Durduran, 2010). 


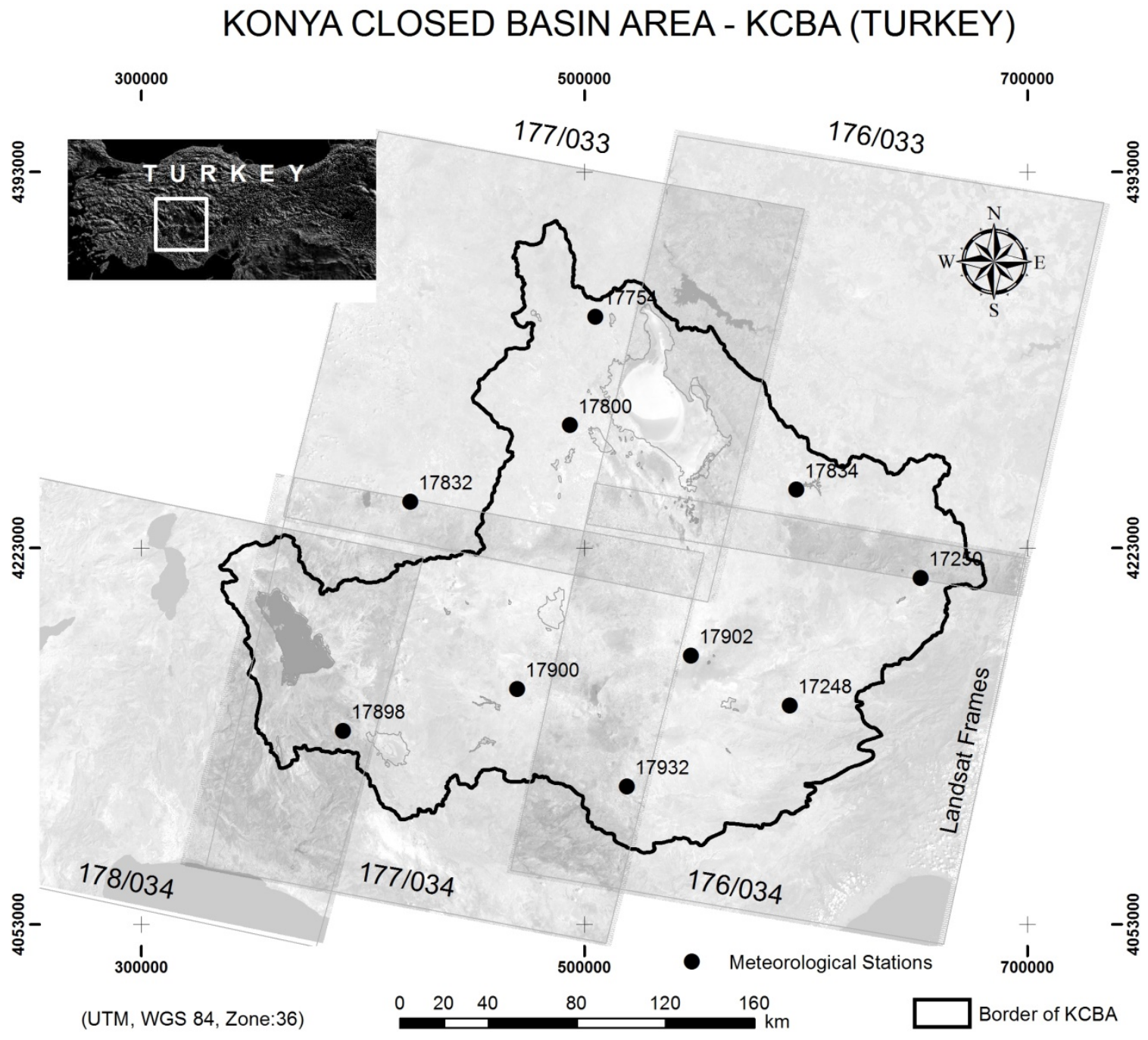

Figure 1. Location of the study area.

\subsection{Field Measurements}

One of the major problems in the validation of remote sensing data with ground truth observation is the dissimilarity between the spatial scales of field thermometers $(<1 \mathrm{~m} 2)$ and that of satellite sensors $(120$ by $120 \mathrm{~m} 2$ for Landsat-5 TIR). The comparison of ground (point) measurements with that of satellite (area averaged) data is meaningful only when the test site is homogeneous in both temperature and emissivity at various spatial scales involved. Accuracy of ground measurements must be assessed, including the natural variability of the surface. Ideal validation of a test site is very difficult to achieve; however, crusted saline soil, bare saline soil, salt and fallow area have been used as most suitable sites for validation (Coll et al., 2005).

The real-time surface temperature measurements were carried out on August 21, 2011 (07:30-11:00 AM, GMT+2) over crusted saline soil, bare saline soil, salt, and fallow area during daytime, cloud-free concurrently to the overpasses time of Landsat-5 at 08:21 AM (GMT+2) over the Salt Lake, Turkey (Path/Row=177/033). 42560 Model Portable Infrared Thermometer with Wireless PC Interface was used for collecting ground surface temperatures to validate the results derived from the Landsat data. Temperature measurements were taken at 40 sample points. 42560 Model of $0.1{ }^{\circ} \mathrm{C}$ resolution measures ground temperature in single channel $(8-14 \mu \mathrm{m})$ with an accuracy of $\pm 0.5^{\circ} \mathrm{C}$. In order to capture the spatial variability of the surface temperature within the land use class at measured site, several readings were recorded at intervals of $100 \mathrm{~m}$ around the site (Figure 2). Average ground temperatures over the land use classes at various measured sites were estimated with maximum standard deviation of $<0.5^{\circ} \mathrm{C}$ for all locations (Srivastava et al., 2009). 

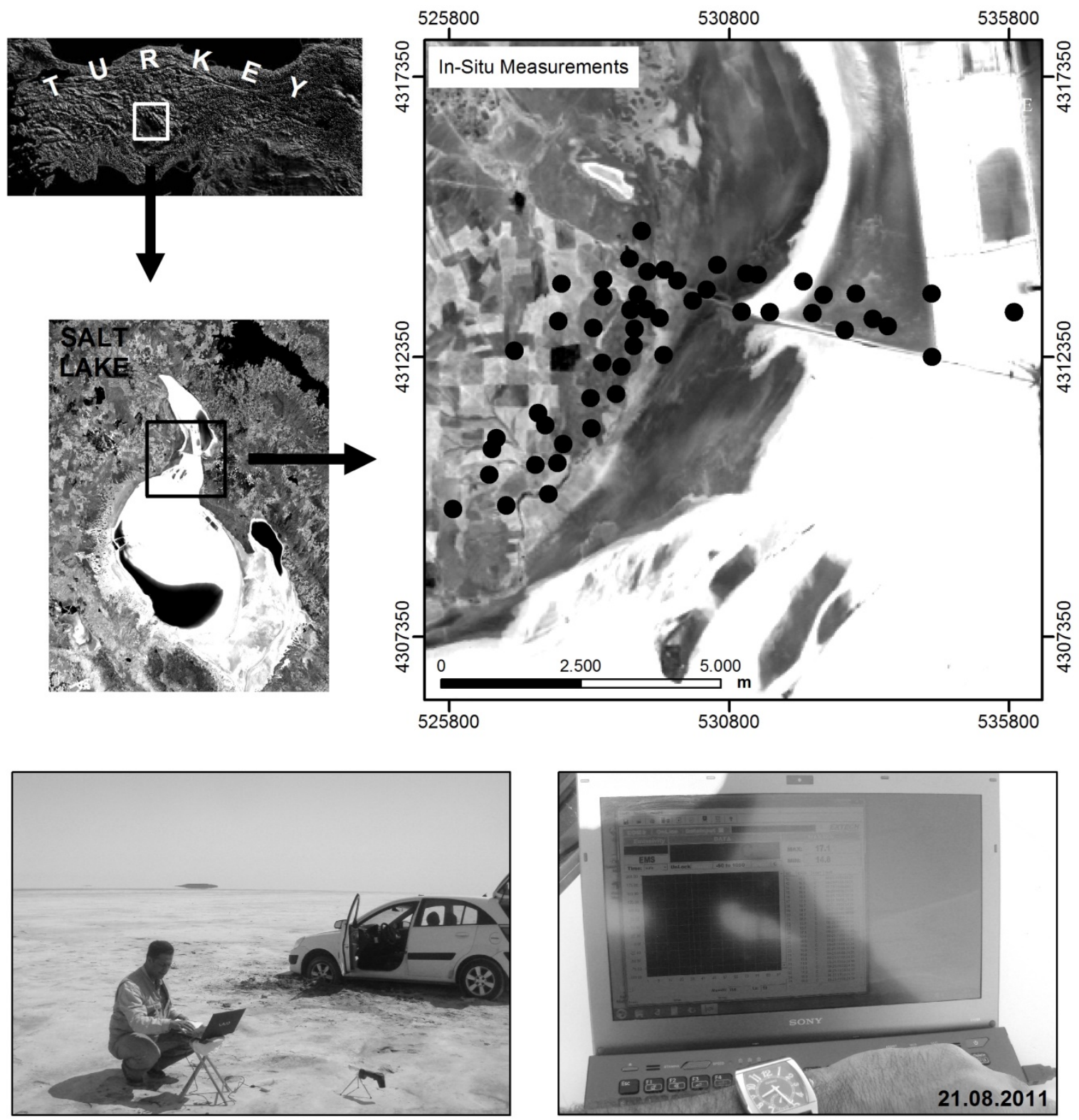

Figure 2. The details of the real-time field measurements performed with the over-pass of Landsat-5 (Real-time measurements were collected on August 21, 2011 (Local time: 07:30-11:00 AM). Landsat-5 overpass: 08:21 AM over the Salt Lake, Turkey (Path/Row=177/033).

\subsection{Landsat Data and Image Processing}

Multitemporal Landsat images along with climatic data were used to explore the dimension of drought effects on water lands and lakes located in our study area (Table 1). A cloud-free Landsat-5 TM image (Path/Row= 177/033) acquired on August 21, 2011 (08:21, GMT+2) was used as real-time satellite remote sensing data.
The Landsat TM instrument has four spectral bands in the visible near infrared-VNIR $(0.45-0.52 \mu \mathrm{m}, 0.52-0.60 \mu \mathrm{m}$, $0.63-0.69 \mu \mathrm{m}$ and $0.76-0.90 \mu \mathrm{m}-30 \mathrm{~m})$, two bands in the short wave infrared-SWIR (1.55-1.75 $\mu \mathrm{m}$ and 2.08$2.35 \mu \mathrm{m}-30 \mathrm{~m})$ and one band in the thermal infrared-TIR regions $(10.4-12.5 \mu \mathrm{m}-120 \mathrm{~m})$. 
Table 1. Landsat-5 TM frames covering the KCBA (Turkey) used in the analysis.

\begin{tabular}{|c|c|c|c|c|}
\hline $\mathbf{1 7 6} / \mathbf{3 3}$ & $\mathbf{1 7 6} / \mathbf{3 4}$ & $\mathbf{1 7 7 / 3 3}$ & $\mathbf{1 7 7 / 3 4}$ & $\mathbf{1 7 8 / 3 4}$ \\
\hline 29.07 .2011 & 29.07 .2011 & 21.08 .2011 & 21.08 .2011 & 28.08 .2011 \\
\hline 19.08 .2007 & 19.08 .2007 & 10.08 .2007 & 25.07 .2007 & 17.08 .2007 \\
\hline 08.08 .2003 & 08.08 .2003 & 15.08 .2003 & 15.08 .2003 & 22.08 .2003 \\
\hline 26.08 .1998 & 26.08 .1998 & 01.08 .1998 & 01.08 .1998 & 08.08 .1998 \\
\hline 09.08 .1989 & 09.08 .1989 & 16.08 .1989 & 16.08 .1989 & - \\
\hline 03.08 .1984 & 03.08 .1984 & 26.08 .1984 & 26.08 .1984 & 16.07 .1984 \\
\hline
\end{tabular}

In the image processing step, satellite remote sensing data were geometrically transformed to real world coordinates using UTM projection and WGS 84 datum. The SPOT-5 Pan data having $5 \mathrm{~m}$ spatial resolution (acquired on April 14, 2005) and base maps (with 1:25 000 scale) were used for the ground control, resulting in a root mean square accuracy of less than a half pixel utilizing approximately 50 ground control points for each image, which are listed in Table 1. After the registration procedure, Landsat- 5 mosaic images were prepared and then they were used as base data covering the KCB. Many techniques have been developed to create image mosaics of satellite images over large areas (Du et al., 2001; Kim et al., 2007). In the study, image mosaicing algorithm of the ERDAS Imagine $\left.{ }^{(}\right)$software was used to produce Landsat-5 image mosaic, which will be used as base data for LST map generation.

Another stage of our study was to produce LST thematic maps using Landsat-5 TM mosaic images. Landsat-5 TM data images for the month of August (1984, 1989, 1998, 2003, 2007 and 2011) were used for generating LST maps. August was selected because this month is the hottest and driest month of the year and also can provide information about the drought conditions at the end of summer season. In order to estimate LST from TIR data, the brightness values of the remotely sensed image's pixels need to be converted into spectral radiance using the sensor calibration data (Markham and Barker, 1986). First, Landsat-5 TM, 2011 and then other historical images were radiometrically corrected to be able to compare with in-situ infrared thermometer measurements and each other (Joshi and Bhatt, 2012). The first equation was used to perform conversion from digital number $(\mathrm{DN})$ to spectral radiance $(\mathrm{L})$ :

$$
L \lambda=\frac{\operatorname{Lmax} \lambda-\operatorname{Lmin} \lambda}{Q \operatorname{calmax}-Q \operatorname{calmin}} \times(Q \operatorname{cal}-Q \operatorname{calmin})+\operatorname{Lmin} \lambda
$$

Where the $\mathrm{L} \lambda$ is the cell value as radiance $(\mathrm{W} /(\mathrm{m} 2 \mathrm{sr}$ $\mu \mathrm{m})$ ), $\mathrm{Q}$ cal is the quantized calibrated digital number, $\mathrm{Q}$ calmin is the minimum quantized calibrated pixel value, and Q calmax is the maximum quantized calibrated pixel value; $\mathrm{LMIN} \lambda$ is the spectral radiance scales to $\mathrm{Q}$ calmin , LMAX $\lambda$ is the spectral radiance scales to $Q$ calmax.

Spectral radiance was converted to brightness temperature by assuming the earth's surface is a black body (Eq. 2) (Orhan et al. 2014; Chander et al, 2009; Coll et al, 2010):

$$
T b=\frac{K 2}{\ln ((K 1 / L \lambda)+1)}-273.15
$$

Where $\mathrm{Tb}$ is the brightness temperature, $\mathrm{L} \lambda$ is the cell value as radiance, $\mathrm{K} 1$ and $\mathrm{K} 2$ are the constants of Landsat-5 calibration. For obtaining the results in Celsius, the brightness temperature is revised by adding the absolute zero $\left(-273.15^{\circ} \mathrm{C}\right)$ (Orhan et al. 2014; Avdan and Jovanovska, 2016)

The next step was used to make the satellite data comparable with the in-situ (LST) measurements. In this step, Equation 3 was used for conversion from radiance to LST value:

$$
T s=\frac{T b}{1+\left(\lambda \times \frac{T b}{\rho}\right) \mathrm{LN} \varepsilon \lambda}
$$

Where $\lambda(11.45 \mu \mathrm{m}$ for Landsat 4,5 and 7 / $10.895 \mu \mathrm{m}$ for Landsat 8 band $10 / 12 \mu \mathrm{m}$ for Landsat 8 band 11) is the emitted radiance wavelength. $\rho(0.01438 \mathrm{mK})$ is generated from the equitation $\rho=h^{*} \mathrm{c} / \mathrm{b}$, in which $\mathrm{h}$ $(6.626 * 10-34 \mathrm{Js})$ is the Planck's constant,c $(2.998 * 108 \mathrm{~m} / \mathrm{s})$ is the velocity of light, and $b$ $(1.38 * 10-23 \mathrm{~J} / \mathrm{K})$ is the Boltzmann constant, and $\varepsilon \lambda$ is the surface emissivity.

The land surface emissivity (LSE $(\varepsilon)$ ) must be known in order to estimate LST. The determination of the ground emissivity is calculated conditionally as suggested in (Sobrino et al. 2004).

$$
\varepsilon \lambda=\varepsilon v \lambda P v+\varepsilon s \lambda(1-P v)+C \lambda
$$

where $\varepsilon \mathrm{V}$ and $\varepsilon S$ are the vegetation and soil emissivities, respectively, $P \mathrm{v}$ is the proportion of vegetation derived from an NDVI based empirical model in Eq.7 by Carlson and Ripley (1997). C $\lambda$ mean surface roughness ( $\mathrm{C}=0$ for a flat surface) taken as a constant value of 0.005 (Sobrino and Raissouni, 2000) .In this study, LSE $(\varepsilon)$ extracted by using NDVI considering three different condition(soil, fully vegetated and mixture of bare soil and vegetation). 
Adapting the approximation of vegetation and soil surface emissivity values from Sobrino et al. (2008), land surface emissivity is expressed for Landsat-5 TM band 6 using the following equation.

$\varepsilon \lambda=\left\{\begin{array}{cc}0.979-0.035 \text { pred, } & N D V I<N D V I s, \\ 0.986+0.004 P v, & N D V I s \leq N D V I \leq N D V I v, \\ 0.99, & N D V I>N D V I v,\end{array}\right.$

Where $\rho$ red is reflectivity values obtained with a sensor band located in the red region. The relationship between emissivities and red reflectivities is is considered to be linear. Sobrino et al. (2008).

A method for calculating Proportion of Vegetation $(P v)$ (Wang et. al 2015). suggests using the NDVI values for vegetation and soil $(\mathrm{NDVIv}=0.5$ and NDVIs $=0.2)$ to apply in global conditions using the following equation. (Sobrino et al. 2004).

$P v=\left[\frac{N D V I-N D V I S}{N D V I v-N D V I S}\right]^{2}$

The NDVI is calculated as a ratio between measured reflectivity in the red and near infrared portions of the electromagnetic spectrum. The NDVI is computed using the following equation.

$N D V I=\frac{N I R-R E D}{N I R+R E D}$

\subsection{Climate Data and Trend Analysis}

Analysis of the climate data series collected in the $\mathrm{KCB}$ can provide insights about the changes in climatic conditions in the region. For this purpose, we analyzed air temperature, precipitation, and pan evaporation data collected at 10 weather stations operated by the State Meteorology Service (Figure 1). All data were in daily timescale and available from 1984 to 2011 . At the first step, we expressed the data as monthly or annual averages (air temperature) or totals (precipitation and pan evaporation).

Trend analysis can be used to understand the longterm variations in time-series data. Various methods can be used to identify trends in data series (e.g., graphical methods, linear regression, Mann-Kendall trend test) (Kundzewicz and Robson 2004). In this study, we used the Mann-Kendall trend test (Kendall 1975, Mann 1945), which is a non-parametric method frequently used for detection of trends in climatic data (e.g., Niedźwiedź v.d. 2009, Partal and Kahya 2006, Brunetti v.d. 2000). The strengths of trends were estimated using the Sen's slope method (Sen, 1968). Sen's slope is also a non-parametric method and can be calculated as the median of the slopes calculated from all pairs of values in the data series.

\subsection{Evaluation of in-situ measurements}

In step of the LST validation, Correlation analysis was performed to investigate the relationships between LST value derived thermal infrared band of the Landsat5 TM image of August 21, 2011 and real-time ground measurement obtained using infrared thermometer. First of all, digital numbers of satellite image were converted to radiance value (Equation 1) and then to LST (Equation 3) to compare real-time in-situ measurements. Real-time ground measurements were obtained at 40 sample points identified around the lake classified as crusted saline soil, salt, bare saline soil, and fallow area. The relationships between converted Landsat-5 TIR data and surface (insitu) measurements are shown in Figure 3. The regression results show that converted Landsat- 5 TIR data and the measured surface temperatures are in good agreement with R2 values about 0.94 in the sample points (Figure 3 ). Here, it can be indicated that the use of real-time data set collected on the same day and hours increased consistency between ground and satellite data.

In this study, in addition to average values of infrared thermometer measurements, minimum and maximum of infrared thermometer measurements values were used for correlation analysis. It is experienced that maximum values negligibly increased the correlation, whereas the minimum values decreased the correlation at the same rate for all spectral ranges (i.e. R2mean: 0.9448; R2min: 0. 9428; R2max: 0.9474).

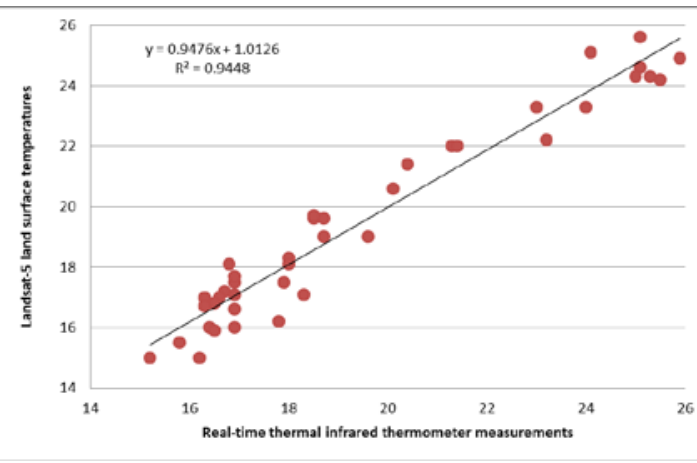

Figure 3. Relationships between real-time (in situ) thermal infrared thermometer measurements and land surface temperatures calculated from Landsat-5 thermal infrared band (Real-time measurements were collected on August 21, 2011 (Local time: 0730-1100 AM). Landsat5 overpass: 0821 AM over the Salt Lake, Turkey (Path/Row=177/033).

\subsection{Interpretation of Surface Temperature Changes}

After relating ground temperature measurements with LST values from Landsat-5 TM data for August 2011, it was found that LST values directly obtained from the appropriate conversion of satellite data into temperatures are providing reliable source of information considering the high correlation value between the ground and satellite data. To analyze the LST changes over the study area, LST images created from multi-temporal Landsat-5 TM data were used. 
Figure 4 illustrates the LST maps of different years obtained from the satellite images. LST values in the KCB showed some significant changes from 1984 to 2011. Among the six years examined, 1984 was the coolest year for the entire basin. For the majority of the basin, the LST were lower than 36oC. Water bodies in the basin have also lower temperatures in this year. Surface temperature of Salt Lake and other water bodies were lower than $21^{\circ} \mathrm{C}$. In general, LSTs were higher in the southern and southeastern parts of the basin. These regions cover the transition zones from terrestrial to Mediterranean or desert climate, therefore, higher temperatures are expected. Major metropolitan areas (such as Konya) are also located in this region, where higher temperatures are expected due to urban heat island effect.

A gradual increase in surface temperatures can easily be identified between 1984 and 2007 for the entire basin.
LST map of 2007 has the highest temperature values compared to other years. Especially northern part of the basin has higher temperature values in 2007. In addition to higher temperatures over the land in August 2007, temperature of Salt Lake surface was between $27^{\circ} \mathrm{C}$ and $33^{\circ} \mathrm{C}$ as well. LST map of 2007 provides useful information about the drought signals within the study area. Results obtained from the analysis of climatic data (below) were also in line with this finding with higher air temperature values in August 2007 compared to other years.

In 2011, some cooling occurs compared to 2007, but the LSTs were still higher than those of 1984 at the majority of the basin. Surface temperature of Salt Lake and other water bodies were apparently higher in 2011, too. Some small regions with lower temperatures can be identified over the basin (e.g., at regions to the south of Salt Lake), which are probably areas converted to agriculture and irrigated since 1984.

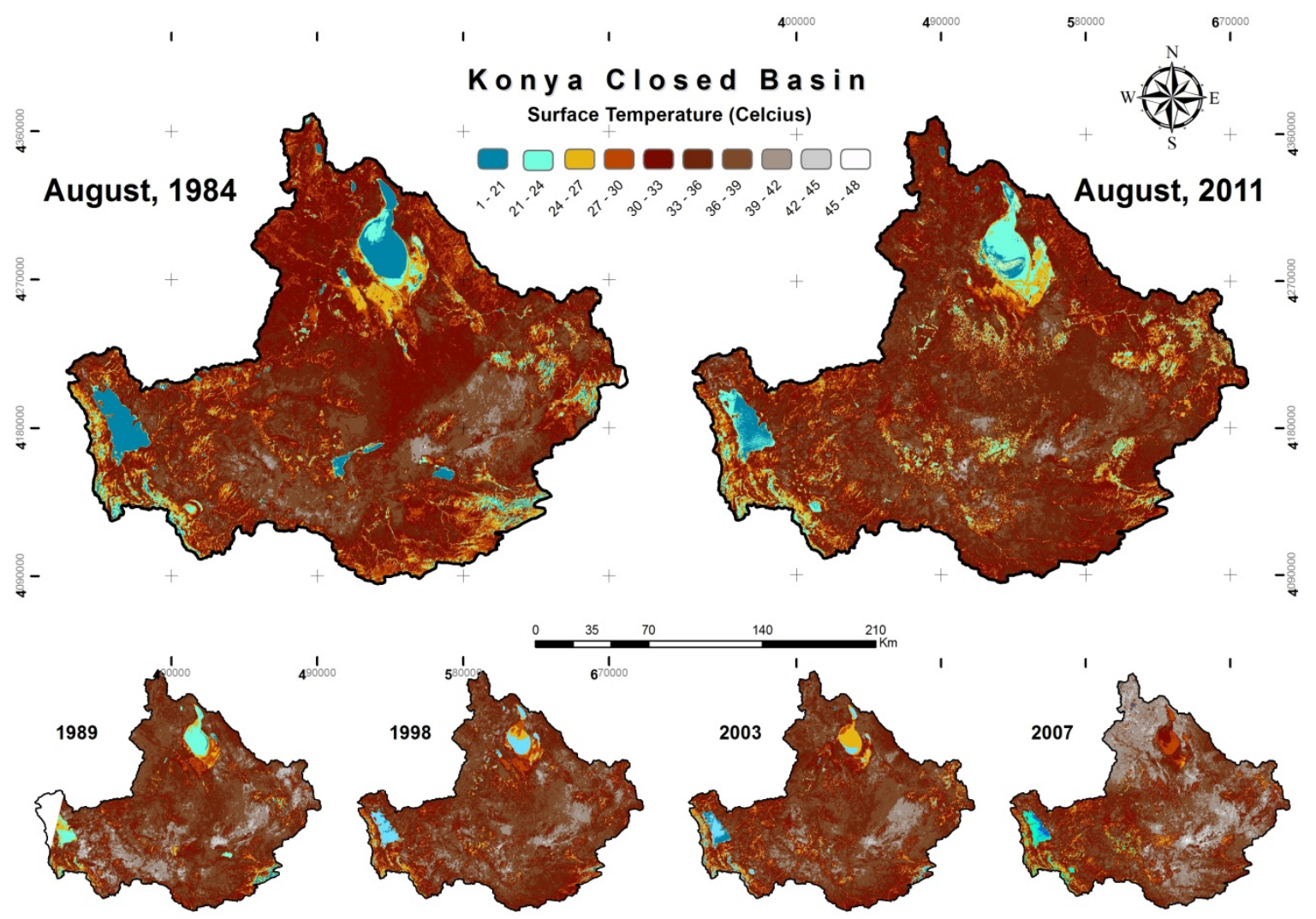

Figure 4. Presentation of land surface temperature changes over the Konya Closed Basin from 1984 to 2011.

\subsection{Analysis of Climatic Data}

Air temperature, precipitation, and pan evaporation data obtained for 10 weather stations in the KCB were analyzed to determine the relationships between climatic conditions and LSTs. All climatic data were analyzed at annual timescale and for the month August.

Table 2 shows average air temperature, average precipitation and average pan evaporation at the KCBA for the years 1984, 1989, 1998, 2003, 2007, and 2011. Figure 5 shows the same parameters for the 1984-2011 period. Averages were calculated based on 10 stations' data. As can be seen both annual average and August average air temperatures and annual and August pan evaporation rates were higher in years 1998 and 2007. Both annual precipitation and August precipitation were lowest in 1998. Based on climatic records, 1998 was probably the hottest and driest year among the years included in the analysis for the KCBA. 
Table 2. Average air temperature, precipitation, and pan evaporation in the Konya Closed Basin (Averages were calculated based on 10 stations' data).

\begin{tabular}{|c|c|c|c|c|c|c|}
\hline Parameter & \multicolumn{2}{|c|}{$\begin{array}{c}\text { Air Temperature } \\
\left({ }^{\circ} \mathrm{C} / \mathrm{yr}\right)\end{array}$} & \multicolumn{2}{c|}{$\begin{array}{c}\text { Precipitation } \\
(\mathrm{mm} / \mathrm{yr})\end{array}$} & \multicolumn{2}{c|}{$\begin{array}{c}\text { Evaporation } \\
(\mathrm{mm} / \mathrm{yr})\end{array}$} \\
\hline $\begin{array}{c}\text { Station No. / } \\
\text { Time Scale }\end{array}$ & Annual & August & Annual & August & Annual & August \\
\hline 1984 & 10.96 & 19.30 & 285 & 5.7 & 1208 & 216 \\
\hline 1989 & 10.97 & 23.60 & 277 & 4.9 & 1281 & 253 \\
\hline 1998 & 12.43 & 24.56 & 277 & 0.9 & 1287 & 297 \\
\hline 2003 & 11.72 & 23.32 & 280 & 2.3 & 1196 & 245 \\
\hline 2007 & 12.09 & 24.76 & 311 & 8.6 & 1286 & 258 \\
\hline 2011 & 11.01 & 22.89 & 312 & 1.8 & 1123 & 248 \\
\hline
\end{tabular}
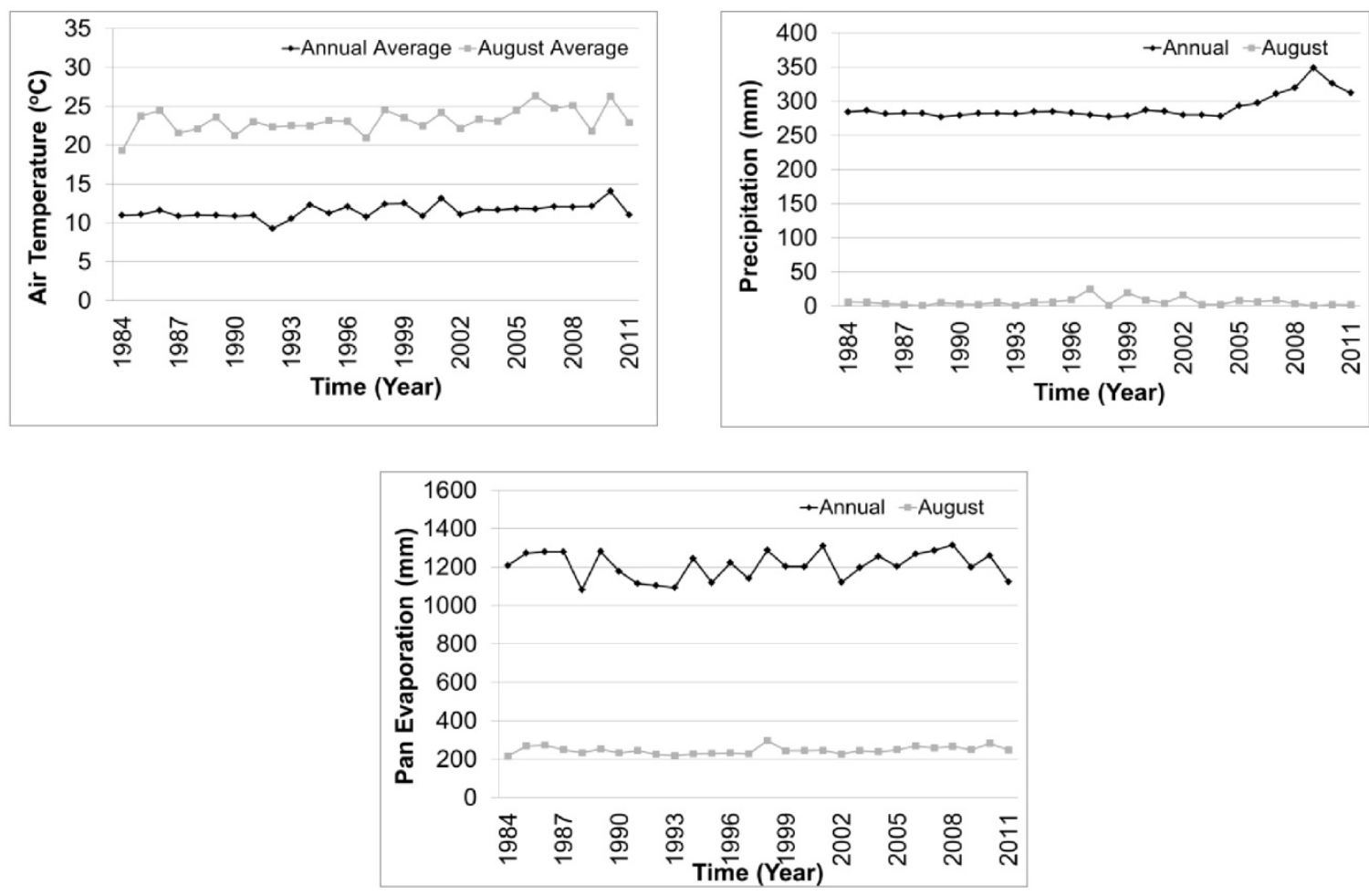

Figure 5. Average air temperature, precipitation, and evaporation in the Konya Closed Basin for the 1984-2011 period. Averages were calculated based on 10 stations' data.

As an additional analysis, we examined the trends in climatic data collected in the basin from 1984 to 2011. The trends in climatic data were determined using the Mann-Kendall trend test and the statistical significances of the trends were evaluated at the 0.05 level. The strengths of changes were estimated using the Sen's Slope method.

Trends in climatic data at annual timescale and for the month August for 10 stations were provided in Table 3. The directions and strengths of trends in annual data were also provided in Figure 6. Annual average air temperature showed upward trends at all stations. Trends detected at 9 stations were statistically significant at the 0.05 level. The rate of change in annual average air temperature data was between $0.03^{\circ} \mathrm{C} / \mathrm{yr}$ and $0.07^{\circ} \mathrm{C} / \mathrm{yr}$, corresponding to $0.84{ }^{\circ} \mathrm{C}$ to $1.96{ }^{\circ} \mathrm{C}$ for the 28 -yr period. Average trend detected for ten stations was $0.05 \mathrm{oC} / \mathrm{yr}$ or $1.40^{\circ} \mathrm{C}$ for the 28 -yr period. The lowest annual average air temperature $\left(9.25^{\circ} \mathrm{C}\right.$ for 10 stations) was detected in the basin in 1992 and the highest annual average air temperature $\left(14.07^{\circ} \mathrm{C}\right.$ for ten stations) was detected in 2010 (Figure 5). In August, average air temperatures changed at an average 
rate of $0.09{ }^{\circ} \mathrm{C} / \mathrm{yr}\left(2.65{ }^{\circ} \mathrm{C}\right.$ for the 28 -yr period) for 10 stations. Trends were again upward and were significant for 8 of 10 stations. For individual stations, the changes were in the range of $0.08{ }^{\circ} \mathrm{C} / \mathrm{yr}$ and $0.13{ }^{\circ} \mathrm{C} / \mathrm{yr}$, corresponding to $2.24{ }^{\circ} \mathrm{C}$ to $3.76{ }^{\circ} \mathrm{C}$ for the 28 -yr period. The trends detected for August were stronger than trends detected at annual timescale for all stations. The average trend detected by the analysis of air temperature time series was very close to the temperature differences detected by LST data calculated based on satellite images.

From 1984 to 2011, annual precipitation showed downward trends at 3 of the 10 stations but none of these trends were statistically significant at the 0.05 level. The remaining 7 stations had upward trends, but only trend detected at one station was statistically significant. Annual precipitation changed at a rate of $-1.83 \mathrm{~mm} / \mathrm{yr}$ to $5.07 \mathrm{~mm} / \mathrm{yr}$ at 10 stations from 1984 to 2011 and the average trend was $0.99 \mathrm{~mm} / \mathrm{yr}$ or $28 \mathrm{~mm}$ for the $28-\mathrm{yr}$ period. The driest year during the 1984-2011 period was 1998 when average annual precipitation for 10 stations was $277 \mathrm{~mm} / \mathrm{yr}$ and the wettest year was 2009 when average annual precipitation for 10 stations was 349 $\mathrm{mm} / \mathrm{yr}$. For August, the change in precipitation was not very strong. For most stations, we detected no change in precipitation rates. Only two stations showed statistically significant changes and these changes were in upward direction.

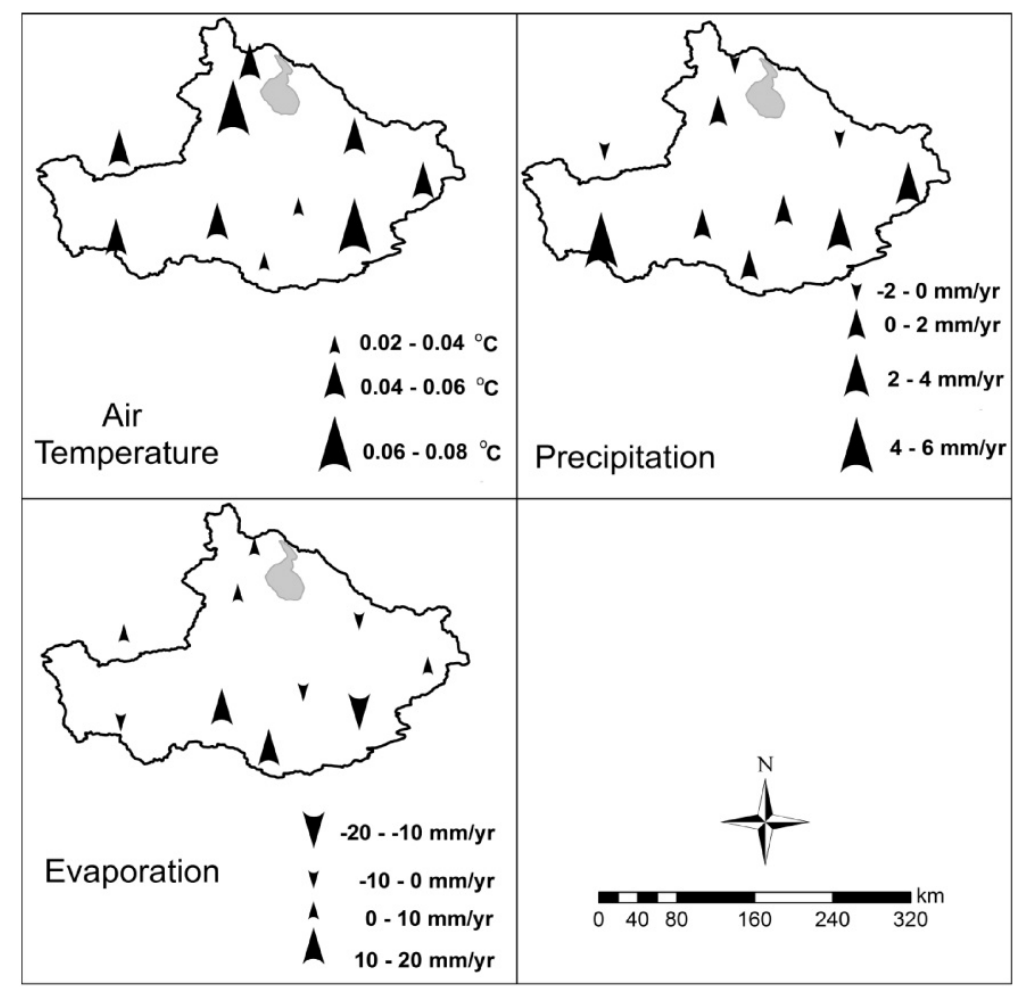

Figure 6. Strengths of trends in annual average air temperature, annual precipitation, and pan evaporation data from 1984 to 2011. Data were plotted at station locations. 
Table 3. Strengths of trends in air temperature, precipitation, and pan evaporation data from 1984 to2011 in the Konya Closed Basin. “*” sign denotes that trends are significant at the 0.05 level.

\begin{tabular}{|c|c|c|c|c|c|c|}
\hline Parameter & \multicolumn{2}{|c|}{$\begin{array}{c}\text { Air Temperature } \\
\left({ }^{\mathbf{}} \mathbf{C} / \mathbf{y r}\right)\end{array}$} & \multicolumn{2}{c|}{$\begin{array}{c}\text { Precipitation } \\
(\mathbf{m m} / \mathbf{y r})\end{array}$} & \multicolumn{2}{c|}{$\begin{array}{c}\text { Evaporation } \\
(\mathbf{m m} / \mathbf{y r})\end{array}$} \\
\hline $\begin{array}{c}\text { Station No. } \\
\text { Time Scale }\end{array}$ & Annual & August & Annual & August & Annual & August \\
\hline $\mathbf{1 7 1 9 1}$ & $0.07^{*}$ & $0.09^{*}$ & 0.55 & 0.00 & 5.12 & $19.46^{*}$ \\
\hline $\mathbf{1 7 1 9 2}$ & $0.06^{*}$ & $0.09^{*}$ & -0.93 & 0.00 & -3.00 & 0.64 \\
\hline $\mathbf{1 7 2 4 6}$ & 0.03 & 0.08 & 0.43 & 0.00 & $17.54^{*}$ & $38.14^{*}$ \\
\hline $\mathbf{1 7 2 4 8}$ & $0.07^{*}$ & $0.13^{*}$ & $3.33^{*}$ & 0.19 & $-17.13^{*}$ & $-26.40^{*}$ \\
\hline $\mathbf{1 7 2 5 0}$ & $0.05^{*}$ & $0.09^{*}$ & 2.52 & 0.66 & $7.97^{*}$ & $28.16^{*}$ \\
\hline $\mathbf{1 7 7 5 4}$ & $0.05^{*}$ & $0.09^{*}$ & -1.83 & 0.00 & 3.86 & 2.59 \\
\hline $\mathbf{1 7 8 3 2}$ & $0.05^{*}$ & $0.09^{*}$ & -0.43 & -0.70 & 1.45 & 13.80 \\
\hline $\mathbf{1 7 8 9 8}$ & $0.04^{*}$ & 0.08 & $5.07^{*}$ & 0.37 & -5.82 & $-15.66^{*}$ \\
\hline $\mathbf{1 7 9 0 0}$ & $0.05^{*}$ & $0.13^{*}$ & 0.75 & 0.00 & $18.81^{*}$ & $29.90^{*}$ \\
\hline $\mathbf{1 7 9 0 2}$ & $0.04^{*}$ & $0.08^{*}$ & 0.48 & 0.00 & -3.59 & -8.51 \\
\hline
\end{tabular}

Pan evaporation data collected at 10 stations in the KCB showed downward trends at 4 stations but only the trend detected in one station was statistically significant at the 0.05 level. At the remaining 6 stations, upward trends were detected and trends at 3 stations were statistically significant. The trend at 10 stations was between $-17.13 \mathrm{~mm} / \mathrm{yr}$ and $8.81 \mathrm{~mm} / \mathrm{yr}$ from 1984 to 2011 and the average trend was $2.52 \mathrm{~mm} / \mathrm{yr}$ or $70.59 \mathrm{~mm}$ for the 28-yr period. Pan evaporation was smallest in 1988 (1082 mm/yr for 10 stations) and largest in 2008 (1314 mm/yr for 10 stations). For August, the trends in pan evaporation data were upward at 7 stations and trends at 6 stations were statistically significant at the 0.05 level. The rates of changes were also stronger than the rates detected at annual time-scale. As no trends are detected in precipitation and upward trends were detected in pan evaporation data, we can say that in general water availability (which can be defined as the difference between precipitation and pan evaporation rates) decreased in the KCB from 1984 to 2011, particularly for the month August.

\section{CONCLUSIONS}

In this study, we examined land surface temperature (LST) changes of Konya Closed Basin (KCB) of Turkey to evaluate drought impact over the region between 1984 and 2011. LST values were obtained by analyzing Landsat 5 TM images acquired in August of 1984, 1989, 1998, 2003, 2007, and 2011. A real-time field work was performed to related LST values with ground measurements. Air temperature, precipitation, and pan evaporation data collected at 10 stations in the basin were also analyzed.

The results show that real-time ground temperature and satellite remote sensing data were in good agreement with correlation coefficient (R2) values of 0.94 . The LST values for six years showed that significant LST changes occurred in the basin from 1984 to 2011. The changes were about $2^{\circ} \mathrm{C}$ and 2007 was the year with the highest LST values for the entire basin.

The results obtained from the analysis of climatic data supports the findings obtained from the LST data. Air temperatures showed significant changes in the KCB from 1984 to 2011. The trends in air temperatures were upward and about $2^{\circ} \mathrm{C}$ during the 28-yr period, which is quite similar to the differences detected based on analysis of the LST data. In precipitation data, trends seemed to be upward but not strong. In pan evaporation, the trends were generally upward and stronger than the trends detected in precipitation. Both air temperature and pan evaporation trends detected for August were stronger than those detected at annual data.

This study also showed the importance of the effect of emissivity value in the calculation of LST. The correlation between the real-time ground temperature and LST, calculated without using emissivity, was $89 \%$ (Orhan et al., 2014) while it is 94\% in this study.

LST changes seen between 1984 and 2011 could be related to climatic changes and land use/land cover changes. LSTs are known to have strong negative connection with vegetation density and positive connection with impervious areas, such as urban areas. In other words, a decrease in vegetation density or an increase in imperviousness can cause increases in LSTs. Based on the analysis of climatic records, it is possible to say that increases in air temperatures and probably evaporation caused water shortages in the region, which, in turn, deteriorated the vegetative cover in the KCB. The urban areas have also expanded in the region from 1984 to 2011, which increased the area covered by impervious surfaces. These two factors together might have contributed to LST changes. 


\section{ACKNOWLEDGEMENTS}

This continuing research project was funded by The Scientific and Technological Research Council of Turkey (TUBITAK; grant number $110 \mathrm{Y} 303$ and The European Space Agency (ESA; grant number 9882). The authors also appreciate the support provided by the Turkish State Meteorological Service providing climatic data for the study.

\section{REFERENCES}

Avdan, U., Jovanovska, G., (2016) Algorithm for Automated Mapping of Land Surface Temperature Using LANDSAT 8 Satellite Data, Journal of Sensors, vol. 2016 Article ID 1480307, 8 pages,. 2016. doi:10.1155/2016/1480307.

Bastiaanssen, W. G. M. and Menenti, M. (1998). A remote sensing surface energy balance algorithms for land (SEBAL) 1. Formulation. Journal of Hydrology, 212, 198-212.

Brunetti, M., Maugeri, M.,Nanni, T. (2000). Long-Term Trends in Extreme Precipitation Events over the Conterminous United States and Canada. Theoratical and Applied Climatology, 65, 165-175.

Cai, G., Xue, Y., Hu, Y., Guo, J., Wang, Y. and Qi, S. (2007). Quantitative study of net radiation from MODIS data in the lower boundary layer in Poyang Lake area of Jiangxi Province, China. International Journal of Remote Sensing, 28, 4381-4389.

Chander, G., Markham, B.L., Helder, D.L., (2009). Summary of current radiometric calibration coefficients for Landsat MSS, TM, ETM+, and EO-1 ALI sensors. Remote Sensing of Environment, 113, 893-903.

Chen, Y.H., Li, X.B., Li, J., Shi, P.J. and Dou, W., (2005). Estimation of daily evapotranspiration using a two-layer remote sensing model. International Journal of Remote Sensing, 26, 1755-1762.

Christóbal, J., Ninyerola, M.Andpons, X., (2008). Modeling air temperature through a combination of remote sensing and GIS data. Journal of Geophysical Research, 113, D13106 doi:10.1029/2007JD009318.

Coll, C., Caselles, V., Galve, J.M. (2005). Ground measurements for the validation of land surface temperatures derived from AATSR and MODIS data. Remote Sensing of Environment, 97, 288-300.

Coll, C., Galve, J.M., Sánchez, J.M., Caselles, V., (2010). Validation of landsat-7/ETM+ thermal-band calibration and atmospheric correction with ground-based measurements. IEEE Transactions on Geoscience and Remote Sensing, 48, 547-555.

Dash, P., Göttsche, F.M., Olesen,F.S., Andfischer, H., (2002). Land surface temperature and emissivity estimation from passive sensor data: theory and practice- current trends. International Journal of Remote Sensing, 23, 2563-2594.

Dogdu, M.S., M. M. Toklu,C., Sağnak, 2007, "Examination of Precipitation and Groundw ater Level Values in Konya Closed Basin”,First Turkish Climate Change Congress, (in Turkish), pp. 394-401. 11-12 April 2007, İstanbul.

Du,Y., J. Cihlar, J. Beaubien, and R. Latifovic, (2001). "Radiometric Normalization, Compositing, and Quality Control for Satellite High Resolution Image Mosaics over Large Areas,” IEEE Transactions on Geoscience and Remote Sensing, 39, 623-634. [doi:10.1109/36.911119].

Durduran, S. S. (2010). Coastline change assessment on water reservoirs located in the Konya Basin Area, Turkey, using multitemporal landsat imagery. Environmental monitoring and assessment, 164(1-4), 453-461.

Florio, E.N., Lele, S.R., Chi Chang, Y., Sterner,R. and Glass, G.E., (2004). Integrating AVHRR satellite data and NOAA ground observations to predict surface air temperature: a statistical approach. International Journal of Remote Sensing, 25, 2979-2994.

Gillespie, A., Rokugawa, S., Matsunaga, T., Cothern, J.S., Hook,S., Andkahle, A.B., (1998). A temperature and emissivity separation algorithm for Advanced Spaceborne Thermal Emission and Reflection Radiometer (ASTER) images. IEEE Transaction on Geoscience and Remote Sensing, 36, 1113-1126.

Jiang, L. and Islam, S. (2001). Estimating of surface evaporation map over southern Great Plains using remote sensing data. Water Resources Research, 37, 329-340.

Joshi, J. P., \& Bhatt, B. (2012). Estimating temporal land surface temperature using remote sensing: A study of Vadodara urban area, Gujarat. International Journal of Geology, Earth and Environmental Sciences, 2(1), 123130.

Kendall, M. G. (1975). Rank Correlation Methods. Griffin, London.

Kim, K., Jezek, K. C. and Liu, H. (2007). Orthorectified image mosaic of Antarctica from 1963 Argon satellite photography: image processing and glaciological applications, International Journal of Remote Sensing, 28, 5357-5373.

Kundzewicz, Z. W.,Robson, A. J. (2004). Change detection in hydrological records: review of methodology. Hydrological Sciences Journal, 49, 7-19.

Kustas,W.P. and Norman, J.M. (1999). Evaluation of soil and vegetation heat flux predictions using a simple twosource model with radiometric temperatures for partial canopy cover. Agricultural and Forest Meteorology, 94, $13-29$

Mann, H. B. (1945). Non-Parametric tests against trend. Econometrica, 13, 245-259. 
Nichol, J.E. and Wong, M.S., (2008). Spatial variability of air temperature and appropriate resolution for satellitederived air temperature estimation. International Journal of Remote Sensing, 29, 7213-7223.

Niedźwiedź, T., Twardosz, R., Walanus, A. (2009). Long-term variability of precipitation series in east central Europe in relation to circulation patterns. Theoretical and Applied Climatology, 98, 337-350.

Markham, B.L., and Barker, J.L. (1986). Landsat MSS and TM post-calibration dynamic rangers, exoatmospheric reflectance and at-satellite temperatures. EOSAT Landsat Tech. Notes, August, 1986.

Norman, J.M., Kustas, W.P. and Humes, K.S. (1995). Source approach for estimating soil and vegetation energy fluxes in observations of directional radiometric surface temperature. Agriculture and Forest Meteorology, 77, 263-293.

Orhan, O., Ekercin, S., Dadaser-Celik, F., (2014) Use of Landsat Land Surface Temperature and Vegetation Indices for Monitoring Drought in the Salt Lake Basin Area, Turkey, The Scientific World Journal, vol. 2014, Article ID 142939, 11 pages.doi:10.1155/2014/142939

Owen, T. W., Carlson, T. N., \& Gillies, R. R. (1998). Assessment of satellite remotely-sensed land cover parameters in quantitatively describing the climatic effect of urbanization.International Journal of Remote sensing, 19, 1663-1681.

Partal, T.,Kahya, E. (2006). Trend analysis in Turkish precipitation data. Hydrological Processes, 20, 20112026.

Qin, Z.H. and Karnieli, A. (1999). Progress in the remote sensing of land surface temperature and ground emissivity using NOAA-AVHRR data. International Journal of Remote Sensing, 20, 2367-2393.

Sen, P. K. (1968). Estimates of the regression coefficient based on Kendall's tau. Journal of American Statistical Association, 39, 1379-1389.

Sobrino, J.A. and Raissouni, N. (2000). Towardremotesensing methods for land cover dynamic monitoring: application to Morocco, International Journal of Remote Sensing,vol.21,no. 2, pp. 353-366.

Sobrino, J.A., Jimenez-Munoz, J. C., Paolini, L. (2004). Land surface temperature retrieval from LANDSAT TM 5. Remote Sensing of Environment, 90, 434-440.

Sobrino, J.A., Jiménez-Muñoz, J.C., Sòria, G., Romaguera, M., Guanter, L., Moreno, J., Martínez, P., (2008). Land surface emissivity retrieval from different VNIR and TIR sensors. IEEE Transactions on Geoscience and Remote Sensing, 46, 316-327.

Srivastava, P.K., Majumdar, T.J., Bhattacharya, A.K. (2009). Surface temperature estimation in Singhbhum Shear Zone of India using Landsat-7 ETM+ thermal infrared data. Advances in Space Research, 43, 15631574.
Su, Z., (2002). The surface energy balance system (SEBS) for estimation of turbulent heat fluxes. Hydrology and Earth System Science, 6, 85-99.

Wang, F., Qin, Z., Song, C., Tu, L., Karnieli, A. Zhao, S., (2015). An improved mono-window algorithm for land surface temper-ature retrieval from landsat 8 thermal infrared sensor data, Remote Sensing, vol. 7, no. 4, pp. 4268-4289. 